Viewpoints and Letters to the Editor are published in Hort- comments on matters of concern to horticulturists. These are Science to provide members of the American Society for Her- not statements of official Society policy nor do they necessarticultural Science an opportunity to share their experiences and ily reflect the views of a majority of the Society's Members.

\title{
Consumer Perceptions of Quality: Key Issues for Horticultural Research
}

\author{
Lawrence S. Lockshin ${ }^{1}$ and W. Timothy Rhodus ${ }^{2}$ \\ Department of Horticulture, The Ohio State University, Columbus, OH 43210
}

\begin{abstract}
Horticultural producers and retailers are experiencing increasing consumer concern regarding food quality and safety. While some of these concerns may be unwarranted, consumers will always express their opinions about a product through their pocketbooks. Lacking information about these trends, producers and retailers have often found themselves out-of-step with changing tastes and preferences.

An alternative and much more profitable approach would be for producers and retailers to better anticipate consumer concerns regarding quality and develop new products, practices, or information that satisfy the consumer's real and perceived needs. An important consequence of this approach is that producers and retailers would need much more information on consumer preferences than they currently possess and would need to develop in-house research programs or fund external researchers to develop the needed information.
\end{abstract}

However, little research at land grant universities examines consumer demand for or economic implications of providing various levels of quality. Consequently, the lack of an explicit consumer orientation in horticultural research may have reduced the earnings of horticultural businesses by forcing them to search for relevant research findings rather than having readily available results from goaloriented research programs.

To better understand this approach, we will discuss the theory and definition of quality. A discussion of the use of perceived quality to enhance profitability will show how the theoretical precepts can be applied. While many of these studies use food products, a few use fresh foods or horticultural products.

Received for publication 4 Sept. 1990. Salaries and research support provided by State and Federal Funds appropriated to the Ohio Agricultural Research and Development Center, The Ohio State Univ. Manuscript no. 256-90. The cost of publishing this paper was defrayed in part by the payment of page charges. Under postal regulations, this paper therefore must be hereby marked $a d$ vertisment solely to indicate this fact.

'Graduate Student, Depts. of Horticulture and Marketing.

${ }^{2}$ Assistant Professor, Depts. of Horticulture and

Agricultural Economics and Rural Sociology.
Perceived quality in general. Quality has been the subject of much research in the marketing literature (Holbrook and Corfman, 1985; Olson, 1972; Rao and Monroe, 1989; Zeithaml, 1988). However, defining quality has eluded most researchers. Authors do not attempt to formally define quality; instead they test subjects' reactions to several product attributes (price, brand, color, etc.). The highest rated grouping of attributes is called "quality." In this sense, quality is what consumers value as attributes of a product or service.

Holbrook and Corfman (1985) presented a formal definition of quality by proposing a three-dimensional classification using the following dichotomies: 1) Implicit/Explicit (within the object or outside the object; 2) Mechanistic/Humanistic (objectively part of the object or associated only with human perception of it; 3) Conceptual/Operational (theoretical vs. useful). The operational-based approach treats quality as a humanistic response to certain properties or characteristics of an object as noted above. This is the approach used by most researchers with multicue or multiattribute models (Allison and Uhl, 1964; Bonner and Nelson, 1985; Christensen, 1983; Dodds and Monroe, 1985; Jacoby et al., 1971; Makens, 1965; Olson, 1972; Rao and Monroe, 1989; Zeithaml, 1988). These models manipulate objective product attributes to trace their effects on subjective quality judgments. These studies use relatively straightforward rating scales to assess perceived quality as a dependent variable.

Although these studies attempt to define quality, Holbrook and Corfman (1985) criticized them for their lack of a theoretical perspective. This absence of an accepted definition of quality has resulted in some studies confusing terms such as quality, flavor, attitude, and satisfaction. Holbrook and Corfman conclude that quality must be defined as one type of value, along with other values, such as beauty, fun, convenience, etc. Their final definition is that quality is an extrinsic, self-oriented, passive value. However, they report that quality differs from other values, such as beauty or convenience, in that quality includes convenience, fun, objective performance, and preference, thus making quality an overall measure. This in- clusiveness further emphasizes the difficulty in theoretically defining quality. Other authors take a more practical viewpoint.

A broader perspective is taken by Olshavsky (1985). He views perceived quality as one aspect of preference formation by consumers. He postulates that consumer preference depends on consumer and environmental variables, such as the mood of the consumer, the urgency of the need for the purchase, the helpfulness of the store personnel, the price, etc. He also concludes that little direct evidence indicates that a strong preference results in an intention to purchase. This means that studies measuring likelihood to buy should simulate the buying process rather than asking which item the consumer likes better. Consumer quality preference should be linked to the desire to purchase.

Other research uses attributes to measure aspects of quality. Monroe has compiled extensive data relating price as a cue to quality (Monroe and Krishnan, 1985; Rao and Monroe, 1989). His work shows that price is an important quality aspect, but that it interacts with consumer information, brand image, and consumer reference prices to produce a quality rating. Alternatively, many studies have shown that brand name recognition is more important to a consumer than actual product differences (Allison and Uhl, 1964; Dodds and Monroe, 1985; Jacoby et al., 1971; Makens, 1965; Rathmell, 1974). Olson (1977) offers an explanation for this approach, which he calls chunking, the collection of a series of valuative cues in one memory trace or chunk. The consumer lumps ratings of various product attributes in one memory "chunk," which is easier to remember and recall than comparing the attributes one by one for every potential choice.

Perceived quality is not just an ephemeral theoretical concept, but a factor that influences brand market share and profitability. Bonner and Nelson (1985) surveyed $>3900$ consumers for their attitudes towards 28 brands and 33 product categories in the general area of food. Quality was found to be a global concept across various food categories. High quality was most often associated with rich/full flavor, natural/fresh flavor, good aroma, and visual appeal. All of these are sensory aspects. Further, when individ- 
ual brand rankings were compared with respect to market share and specific quality rating, the top brands had high sensory ratings that differentiated them from other brands. This result shows that the strength of a brand is related to its quality perception by consumers. It is important for producers and researchers to realize that market share and sales are a directly related to consumer perceptions of quality.

Jacobson and Aaker (1987) used Profit Impact of Market Strategies data to investigate quality as a strategic tool. They concluded that quality can be and is used as a strategic tool. High quality led to increased return on investment and increased market share across a sample of four business groupings. Those businesses with a high rating of perceived quality were more profitable than those similar businesses with lower rankings.

Perceived quality has been a widely researched aspect of consumer behavior. Although there are still theoretical questions about a universal definition of quality, measurements of quality perceptions by consumers are valuable. These measurements allow researchers and businesses to devise the proper marketing mix to attract consumers. This mix includes the product itself, the price, the promotional strategy, and the distribution/retail channels to use. Recent research has shown that a high quality image leads to higher profits and a greater market share, all other things being equal.

Horticultural research on quality. There is no doubt that horticultural research is concerned with quality. A search of the Agricola database revealed $>25,000$ entries that mention the word quality. However, only very few use quality in the context of consumer perception. There are three likely reasons for this situation. First, there is a great deal of proprietary research by food companies that is never published. Although this research is important, most horticultural products are not processed and marketed by food companies. Second, quality measures made by researchers in horticulture are generally related to physical attributes that may not be relevant to consumer perceptions. Third, research agendas in horticulture do not translate product/process implications into consumer benefits.

Eastlack (1964), a food company researcher, describes a method for measuring consumer flavor preferences that can be used in product design. Christensen (1983) explores the effect of food color on aroma and flavor perception by consumers. These methodologies are important for finding the effects of specific attributes on sensory perception and then quality.

Research by Brooker and Jordan examines the dollar impact of important quality characteristics to wholesalers and consumers using the technique of hedonic price estimation (Brooker et al., 1986; Jordan et al., 1985a, 1985b). This method estimates the relative value of improving specific quality attributes such as color, size, ripeness, and nutrition for a crop at a single point in the marketing channel. For example, Jordan et al. (1985a) found that each added gram of weight per tomato raises the wholesale price of a box by $\$ 0.02$. This type of data is very useful in deciding "best" horticultural practice based on economics, not just product attributes. The producer can weigh the increased benefit vs. the cost of producing that benefit.

Horticultural products viewed as services. Although the term "product" is most often used when referring to horticultural production, there is some commonality with "service" that should be considered, especially for nonprocessed products. The issues of nonstandardization and high level of experiencial attributes (those attributes known only by experience) are two features of typical services that horticultural products also share. Zeithaml (1981) details differences between goods and services in terms of how consumers perceive the ease of product evaluation before purchasing. She proposes that most goods range from "easy" to "somewhat difficult" to evaluate, while most services range from "somewhat difficult" to "difficult". Those goods and services that overlap in the middle, "somewhat difficult", are classed as high in experiencial attributes, which is exactly where most horticultural products belong. A consumer can look at a tomato or taxus, but his experience of that product is limited before purchase.

Goods that cannot be experienced before purchase are also higher risk for consumers since they are difficult to return after purchase (Eiglier et al., 1977). This risk factor also makes consumers more brand conscious (Zeithaml, 1988). A brand, once tested and liked, is a safe choice. Also, offering guarantees of satisfaction is easier with brands and more likely to be taken seriously. These offers add value to the brand and allow a higher price. In fact, higher quality is often signalled by higher prices in the absence of other cues (Monroe and Krishnan, 1985, Olson, 1977; Rao and Monroe, 1989).

Key perspectives for horticultural researchers. This paper has presented a review of the research related to consumer perceptions of quality and its usefulness in developing marketing strategies. While much consumer product research has been conducted, there is a lack of this research with horticultural products. As such, horticultural producers and retailers can benefit from an increased emphasis on the consumer implications of horticultural research. This alternative viewpoint is not incompatible with existing research and would not require a major change in research strategies. However, a few additions to research protocols will go a long way toward enhancing the consumer perspective of horticultural research.

One small addition would be simply to collect the costs of adding the various treatments being tested to the overall cost of pro- duction. Once it is known how much is needed to produce a certain effect, an economist or market researcher can figure the cost-benefit ratio of the treatment. Although this seems simple and self-evident, records of these costs are seldom kept. Cost-benefit analysis can take many directions. From a strict monetary sense, one can strive for lower costs with constant benefits, increased benefits with constant costs, or increased costs and benefits. Alternatively, a noncost perspective could look at safety vs. risk for the producer and consumer, earlier vs. later maturity, and more vs. less production. Each of these perspectives could be evaluated for consumer perception of final product quality and price sensitivity.

Obviously, consumer input is required; this is the more costly aspect. This approach could be implemented by organizing consumer panels in each department to help evaluate the potential benefits of various projects. While not all projects would be reviewed because of their basic science orientation, much research is geared toward making existing products better in some way and would, therefore, benefit from consumer input. Also, this review process could provide the mechanism for involving researchers from other departments, such as agricultural economics and marketing. As a result, it is likely that new and/or existing research programs would become more focused on the end user as well as encompassing the skills of a broader variety of researchers.

Existing research in marketing has established the value of knowing which cues consumers use to evaluate products. The same methodologies could be used on horticultural products. Christensen (1983) has already established the general role of color in enhancing aroma and flavor perceptions. By using consumers to confirm which attributes are attractive, applied horticultural researchers could better develop priority areas for product improvement. Additionally, consumers could be used to help researchers better understand the extent to which horticultural products provide a certain service while being consumed. This information can be used to identify physical and nonphysical attributes that correspond to the consumer's definition of quality, e.g., freshness, beauty, uniqueness.

Establishing interdisciplinary teams of researchers from economics, marketing, and horticulture will in the long run provide a more efficient and effective model for research than the current approach, which emphasizes individual specialization. While this practice is well underway within many European research stations and to some extent within the land grant system, additional attention within land grant institutions needs to be focused on this methodology for organizing research.

\section{Literature Cited}

Allison, R.I. and K.P. Uhl. 1964. Influence of 
beer brand identification on taste perception. J. Mktg. Res. 1:36-39.

Bonner, P.G. and R. Nelson. 1985. Product attributes and perceived quality: foods, p. $65-80$ In: J. Jacoby and J.C. Olson (eds.). Perceived quality. Lexington Books, Lexington, Mass.

Brooker, J.R., D.B. Eastwood, and D.E. Terry. 1986. Predicting food prices from estimated implicit values of nutritional characteristics. Univ of Term. Agr. Expt. Sta. Res. Rpt. 86-101.

Christensen, C.M. 1983. Effects of color on aroma, flavor and texture judgments of foods. J. Food Sci. 48:787-790.

Dodds, W.B. and K.B. Monroe. 1985. The effect of brand and price information on subjective product evaluations, p. 85-90. In: E.C. Hirshman and M.B. Holbrook (eds.). Advances in consumer research, vol. 12. Assn. for Consumer Res., Provo, Utah.

Eastlack, J.O. 1964. Consumer flavor preference factors in food product design. J. Mktg. Res. $1: 38-42$.

Eiglier, P., E. Langeard, C.H. Lovelock, J.E.G Bateson, and R.F. Young. 1977. Marketing consumer services: new insights. Mktg. Sci. Inst, Cambridge, Mass.

Holbrook, M.B. and K.P. Corfman. 1985. Qual- ity and value in the consumption experience: Phaedrus rides again, p. 31-58. In: J. Jacoby and J.C. Olson (eds.). Perceived quality. Lexington Books, Lexington, Mass.

Jacobson, R. and D.A. Asker. 1987. The strategic role of product quality. J. Mktg. 51:31-44.

Jacoby, J., J.C. Olson, and R.A. Haddock. 1971. Price, brand name, and product composition characteristics as determinants of perceived quality. J. Applied Psychology 55:570-579.

Jordan, J.L., R.L. Shewfelt, S.E. Prussia, and W.C. Hurst. 1985a. Estimating the price of quality characteristics for tomatoes: aiding the evaluation of the postharvest system. HortScience 20:203-205.

Jordan, J.L., R.L. Shewfelt, W.C. Hurst, and S.E. Prussia. 1985b. Pricing quality attributes at the wholesale level. J. Food Distrib. 16(3):11-15.

Makens, J.C. 1965. Effect of brand preference upon consumer's perceived taste of turkey meat. J. Applied Psychology 49:261-263.

Monroe, K.B. and R. Krishnan. 1985. The effect of price on subjective product evaluations, $\mathrm{p}$. 209-232. In: J. Jacoby and J.C. Olson (eds.). Perceived quality. Lexington Books, Lexington, Mass.

Olshavsky, R.W. 1985. Perceived quality in con- sumer decision making: an integrated theoretical perspective, p. 3-30. In: J. Jacoby and J.C. Olson (eds.). Perceived quality. Lexington Books, Lexington, Mass.

Olson, J.C. 1972. Cue utilization in the quality perception process. A cognitive model and an empirical test. PhD Diss., Purdue Univ., Lafayette, Ind.

Olson, J.C. 1977. Price as an informational cue, p. 267-286. In: A.G. Woodside et al. (eds.). Consumer and industrial buying behavior. Elsevier North-Holland, New York.

Rae, A.R. and K.B. Monroe. 1989. The effect of price, brand name, and store name on buyers' subjective product assessments. J. Mktg. Res. 26:351-357.

Rathmell, J.M. 1974. Marketing in the service sector. Winthrop, Cambridge, Mass.

Zeithaml, V.A. 1981. How consumer evaluation processes differ between goods and services, $\mathrm{p}$. 186-190. In: J. Donnelly and W. George (eds.). Marketing of services. Amer. Mktg. Assn., Chicago.

Zeithaml, V.A. 1988. Consumer perceptions of price, quality, and value: a means-end model and synthesis of evidence. J. Mktg. 52:2-22. 